\title{
Biological response to pre-mineralized starch based scaffolds for bone tissue engineering
}

\author{
A. J. SALGADO ${ }^{1,2, *}$, J. E. FIGUEIREDO ${ }^{1,2,3}$, O. P. COUTINHO ${ }^{1,3}$, R. L. REIS ${ }^{1,2}$ \\ ${ }^{1} 3 B$ 's Research Group, Biomaterials, Biodegradables and Biomimetics, University of Minho, \\ Campus de Gualtar, 4710-057 Braga, Portugal \\ Email: asalgado@dep.uminho.pt \\ ${ }^{2}$ Department of Polymer Engineering, University of Minho, Campus de Azurém, 4800-058, \\ Guimarães, Portugal \\ ${ }^{3}$ Department of Biology, University of Minho, Campus de Gualtar, 4710-057 Braga, Portugal
}

It is known that calcium-phosphate (Ca-P) coatings are able not only to improve the bone bonding behaviour of polymeric materials, but at the same time play a positive role on enhancing cell adhesion and inducing the differentiation of osteoprogenitor cells. Recently an innovative biomimetic methodology, in which a sodium silicate gel was used as a nucleative agent, was proposed as an alternative to the currently available biomimetic coating methodologies. This methodology is especially adequate for coating biodegradable porous scaffolds. In the present work we evaluated the influence of the referred to treatment on the mechanical properties of 50/50 (wt\%) blend of corn starch/ethylene-vinyl alcohol (SEVA-C) based scaffolds. These Ca-P coated scaffolds presented a compressive modulus of $224.6 \pm 20.6$ and a compressive strength of $24.2 \pm 2.20$. Cytotoxicity evaluation was performed according ISO/EN 10993 part 5 guidelines and showed that the biomimetic treatment did not have any deleterious effect on L929 cells and did not inhibit cell growth. Direct contact assays were done by using a cell line of human osteoblast like cells (SaOS-2). $3 \times 10^{5}$ cells were seeded per scaffold and allowed to grow for two weeks at $37^{\circ} \mathrm{C}$ in a humidified atmosphere containing $5 \% \mathrm{CO}_{2}$. Total protein quantification and scanning electron microscopy (SEM) observation showed that cells were able to grow in the pre-mineralized scaffolds. Furthermore cell viability assays (MTS test) also show that cells remain viable after two weeks in culture. Finally, protein expression studies showed that after two weeks osteopontin and collagen type I were being expressed by SaOS-2 cells seeded on the pre-mineralized scaffolds. Moreover, alkaline phosphatase (ALP) activity was higher in the supernatants collected from the pre-mineralized samples, when compared to the control samples (non Ca-P coated). This may indicate that a faster mineralization of the ECM produced on the pre-mineralized samples was occurring. Consequently, biomimetic pre-mineralization of starch based scaffolds can be a useful route for applying these materials on bone tissue engineering.

(C) 2005 Springer Science + Business Media, Inc.

\section{Introduction}

Reconstruction of extensive orthopaedic bone defects is still a major problem affecting millions of people world-wide, which contemporary medicine has yet to solve. Besides the use of non-degradable prosthesis, common therapeutics are focused on the use of bone autografts. These present a series of disadvantages such as limited availability, risk of infection, increased blood loss and morbidity of the donor site [13].

Tissue engineering has been emerging as a valid approach to circumvent the limitations of the described therapies. In this approach, osteogenic cells obtained from the patient are implanted onto temporary 3D biodegradable porous structures (scaffolds). This structure acts as a temporary physical support to guide new tissue regeneration, until the entire material matrix is totally degraded and up taken by the neo tissue. Ideally these temporary scaffolds should be porous in order to accommodate cell growth and facilitate both tissue regeneration and vascularization [4-6]. Furthermore, they should also be biocompatible, mechanically strong and have a biodegradation rate similar to the cell/tissue growth rates [4-6]. Still regarding bone tissue

*Author to whom all correspondence should be addressed. 
engineering three more properties should be considered: (i) the material should establish a stable direct connection, both structural and functional, with the patients bone [7], and the material should be (ii) osteoinductive and (iii) osteoconductive, for recruitment of mesenchymal progenitor cells and guided bone deposition on the scaffolds surface [8].

If considering these three last key points, calcium phosphate bioceramics would be the ideal materials. Within these hydroxyapatite (HA) and $\beta$-tricalcium phosphate $(\beta$-TCP), are excellent candidates for bone regeneration because their chemical compositions are similar to the inorganic components of human bone. When implanted in vivo these materials bind to bone trough a bone like apatite layer at the interface or bind directly to bone [6]. Moreover, they have also shown to be osteoconductive [8]. However, porous calcium phosphate bioceramics are very brittle, which limits their mechanical properties and hence their use in any type of load bearing situation $[5,6]$.

Biodegradable polymers are an alternative to the materials discussed above. However, typically, they do not present adequate bone bonding, osteoconductive and osteoinductive properties. One existing solution to overcome this problem is the deposition of a calciumphophate (Ca-P) layer, with a composition similar to the inorganic component (HA) of bone, on the surface of the polymeric 3D porous structures. After the deposition, materials should exhibit better bone bonding behaviour, as well as, better cell adhesion, proliferation and differentiation profiles of osteoprogenitor cells. This behaviour have been previously obtained by different authors such as Zhang et al. [7], ter Brugge et al. [9], Hulshoff et al. [10], Chang et al. [11] and Ong et al. [12].

Starch based biodegradable materials have been recently proposed for a wide range of biomedical bone related applications, including bone tissue engineering scaffolding [13-16]. In order to improve the cell adhesion to the materials, and in spite of all the difficulties arising from the $\mathrm{pH}$ changes and continuous degradation of substrate surface, a series of biomimetic $\mathrm{Ca}-\mathrm{P}$ coating methodologies were developed. These techniques allow the deposition of a Ca-P layer on the surface of biodegradable starch based polymers [17-19]. As it was reported by Oliveira et al. [18, 19] these methodologies produce a partially amorphous $\mathrm{Ca}-$ $\mathrm{P}$ coating that is similar to natural HA. They were successfully applied on both compact and porous structures for bone tissue engineering scaffolding applications. One of such methodologies is based on the use of sodium silicate gel as an alternative nucleating agent. This agent is applied before the immersion in a simulated body fluid (SBF) solution to promote apatite nucleation and growth [19]. With this method, it is possible to diminish the incubation period for the formation of an apatite coating, when compared to the traditional biomimetic routes, which use bioactive glass particles as nucleating agents [17]. This methodology is also especially adequate to coat uniformly the surface and the bulk of porous scaffolds.
The present study reports on the biological response (cytotoxicity, cell adhesion and protein expression) of human osteoblast like cells to previously mineralized starch based scaffolds. The influence of the already referred biomimetic treatment on the mechanical properties of the native material was also addressed. Results showed that the Ca-P coatings were non toxic. Moreover the growth rate of human osteoblast like cells was similar between the non coated and biomimetic coated samples. Alkaline phosphatase levels were higher in the Ca-P coated samples, which may indicate that the coatings may be affecting the protein and gene expression profile of human osteoblast like cells.

\section{Materials and methods}

\subsection{Scaffolds production and pre-mineralization}

The polymer used in the present study was a 50:50 (wt\%) blend of corn starch/ethylene-vinyl alcohol (SEVA-C, Novamont, Italy). Scaffolds were obtained by using a technology based on extrusion with blowing agents, previously described by Gomes et al. [13]. Briefly, after being processed, scaffolds were cut in $5 \times 5 \times 5 \mathrm{~mm}^{3}$ cuboids, after which the process of pre-mineralization was started. For that purpose samples were soaked in a commercially available sodium silicate solution (Sigma Aldrich, USA) for $24 \mathrm{~h}$, in the end of which samples were allowed to dry and immersed in a simulated body fluid solution (SBF) for 14 days, as described previously [18, 19].

\subsection{Scaffolds characterization}

Calcium-phosphate layer formation, as well as its morphology, were characterized by scanning electron microscopy (SEM) in a Leica Cambridge S360 (Leica Cambridge, UK) equipment. All the samples were previously gold coated in a Sputter Jeol JFC 1100 equipment.

Mechanical properties of the porous structures were carried out in order to evaluate if the referred biomimetic treatments had any effect on the mechanical stability of the scaffolds. Mechanical compressive experiments were carried out in an Instron 4505 universal testing machine (Instron, USA), using a load cell of $50 \mathrm{kN}$. Samples $(n=6)$ were previously cut in cylinders with $1.5 \mathrm{~mm}$ of diameter by $1 \mathrm{~cm}$ of height. The compression tests were carried out at a crosshead speed of $2 \mathrm{~mm} / \mathrm{min}\left(4.7 \times 10^{-5} \mathrm{~m} / \mathrm{s}\right)$, until fracture or obtaining a maximum reduction in samples' height of $60 \%$. Non-treated samples $(n=6)$ were used as controls.

\subsection{Cytotoxicity assays}

The cytotoxicity of the developed Ca-P coatings was evaluated according to ISO/EN 109935 guidelines [20] namely short MEM extraction and MTS tests, both using a $24 \mathrm{~h}$ extraction period. Culture medium with no extraction material and latex rubber were used, 
respectively, as negative and positive controls. Furthermore, and in order to evaluate if the treatments caused any deleterious effects on the materials properties, noncoated SEVA-C scaffolds were also used.

Cells selected for the present experiment were a cell line of rat fibroblasts-L929, obtained from the European Collection of Cell Cultures (ECACC). Cells were grown as monolayer cultures in Dulbecco's modified eagle medium (DMEM, Sigma, USA) supplemented with 10\% Foetal bovine Serum (FBS, Biochrome, Germany) and $1 \%$ of antibiotics/antimicotics solution (Sigma), and trypsinized before the experiments. For the MEM extraction tests, cells were seeded in 24 well plates, at a density of $1.25 \times 10^{5}$ cells $(n=3)$. For the MTS test, cells were seeded in 96 well plates $(n=6)$, at a density of $2 \times 10^{4}$ cells/well. In both cases, cells were previously incubated for $24 \mathrm{~h}$ at $37^{\circ} \mathrm{C}$ in a humidified atmosphere containing $5 \% \mathrm{CO}_{2}$.

Regarding the MEM extraction test, in all experiments a constant ratio of material weight/extract fluid of $0.2 \mathrm{~g} / \mathrm{ml}$ was used, while for positive control the ratio material outer surface/extraction fluid was $2.5 \mathrm{~cm}^{2} / \mathrm{ml}$. Tested material $(n=6)$, non-coated SEVA-C scaffolds $(n=6)$ and positive control (latex rubber) $(n=6)$ were extracted during $24 \mathrm{~h}$ under constant agitation at $60 \mathrm{rpm}$ and $37^{\circ} \mathrm{C}$, with complete culture medium as the extraction fluid. For the beginning of the tests, the culture medium in each well was replaced with the same amount, $2 \mathrm{ml}$, of extraction fluid. The extracts of each material were evaluated in three-fold. After adding the extraction fluid the plates were incubated at $37^{\circ} \mathrm{C}$ in a humidified atmosphere containing $5 \% \mathrm{CO}_{2}$. After 24 , 48 , and $72 \mathrm{~h}$ the reaction of the cells to the extracts was evaluated microscopically, compared to the negative control and scored for the confluency of the monolayer, degree of floating cells and changes in cellular morphology (see scores on Table I).

At the end of the test (after $72 \mathrm{~h}$ ) cells were trypsinized and the percentage of growth inhibition was determined by counting cells using the trypan blue exclusion test. Finally, the scores correspondent to the above referred parameters were combined (the four parameters have been given an equal weight, i.e., 25\%), resulting in a final cytotoxicity index ranging from 0 to 8 (Table II).

TABLE I Quantitative and qualitative scores used in the cytotoxicity tests

\begin{tabular}{|c|c|c|c|c|}
\hline Score & $\begin{array}{l}\text { Confluency } \\
(\%)\end{array}$ & $\begin{array}{l}\text { Floating } \\
\text { cells } \\
\text { cells }(\%)\end{array}$ & $\begin{array}{l}\text { Change of } \\
\text { cellular } \\
\text { morphology } \%\end{array}$ & $\begin{array}{l}\text { Inhibition } \\
\text { of cell } \\
\text { growth }(\%)\end{array}$ \\
\hline 0 & 100 & 0 & $\begin{array}{l}\text { No changes during } \\
\text { test period }\end{array}$ & $0-10$ \\
\hline 1 & 90-100 & $0-5$ & $\begin{array}{l}\text { Slight changes, few } \\
\text { cells affected }\end{array}$ & $10-30$ \\
\hline 2 & $60-90$ & $5-10$ & $\begin{array}{l}\text { Mild changes, some cells } \\
\text { round/spindle shaped }\end{array}$ & $30-50$ \\
\hline 3 & $30-60$ & $10-20$ & $\begin{array}{l}\text { Moderate changes, many } \\
\text { cells round/spindle }\end{array}$ & $50-70$ \\
\hline 4 & $0-30$ & $>20$ & $\begin{array}{l}\text { Severe changes, about all } \\
\text { show morphological } \\
\text { changes }\end{array}$ & $70-100$ \\
\hline
\end{tabular}

TABLE II Cytotoxicity index

\begin{tabular}{lll}
\hline Cytotoxicity index & Reactivity & Score \\
\hline $0-1$ & None & Pass \\
$1-3$ & Slightly toxic & Pass \\
$3-5$ & Mildly toxic & Retest \\
$5-7$ & Moderately toxic & Fail \\
$7-8$ & Severely toxic & Fail \\
\hline
\end{tabular}

The grading system was as follows: For cytotoxicity index ranging from 0 to 3 , the material is considered to pass the cytotoxicity test, for index between 3 and 5 is advised to repeat the test and for index higher than 5 the material is considered to fail the test.

CellTiter 96 ${ }^{\circledR}$ One solution Cell proliferation Assay kit (Promega, USA) is based on the bioreduction of the substrate, (3-(4,5-dimethylthiazol-2-yl)-5-(3carboxymethoxyphenyl)-2(4-sulfophenyl)-2H tetrazolium) (MTS), into a brown formazan product by dehydrogenase enzymes in metabolically active cells, being commonly used for cell viability evaluation $[15,16]$. This assay followed the same extraction procedure described previously for the MEM test, using $200 \mu \mathrm{l}$ of extraction fluid/well. After $72 \mathrm{~h}$, the extract fluid was removed and $200 \mu \mathrm{l}$ of a mixture containing culture medium without FBS and phenol red, and MTS were added into each well. Cells were then incubated for $3 \mathrm{~h}$ at $37^{\circ} \mathrm{C}$ in a humidified atmosphere containing $5 \%$ $\mathrm{CO}_{2}$, in the end of which optical density (O.D.) was measured in a multi-well plate reader (Molecular Devices, USA) at $490 \mathrm{~nm}$. The mean O.D. $490 \mathrm{~nm}$ value obtained for the negative control was standardized as $0 \%$ of metabolism inhibition.

\subsection{Direct contact assays \\ 2.4.1. Cell seeding}

For direct contact assays a cell line of human osteoblast like cells, SaOS-2, was selected. Cells were grown as monolayer cultures in DMEM medium supplemented with $10 \% \mathrm{FBS}, 1 \%$ antibiotics/antymicotics solution, 5 $\mathrm{mM} \beta$-glycerophosphate (Sigma, USA) and $50 \mu \mathrm{M}$ of ascorbic acid (Sigma, USA) up to the 10th passage. At that time cells were trypsinized, centrifuged and resuspended in complete culture medium. Aliquots of $20 \mu \mathrm{l}$ containing $3 \times 10^{5}$ cells were then seeded on top of each pre-mineralized scaffold. Two hours after cell seeding $1 \mathrm{ml}$ of culture medium was added into each well and cells/scaffolds constructs were incubated for 2 weeks at $37^{\circ} \mathrm{C}$ in a humidified atmosphere containing $5 \% \mathrm{CO}_{2}$, with medium changes every 3-4 days. Uncoated scaffolds were used as controls.

\subsubsection{Cell adhesion}

Cell adhesion to pre-mineralized and non-mineralized starch based scaffolds was assessed after 1, 7 and 14 days. For that purpose cells/scaffolds constructs were first washed in $0.15 \mathrm{M}$ PBS, fixed in $2.5 \%$ glutaraldehyde solution in PBS, submitted to a ethanol series of $50,70,80,90$ and $100 \%$ for $2 \times 15 \mathrm{~min}$, and finally washed once again in PBS. Samples were then gold coated in a Sputter Jeol JFC 1100 equipment and 
observed under a Leica Cambridge S360 scanning electron microscope.

\subsubsection{Cell viability assay}

Cell viability was assessed after 12 h, 7 and 14 days by using the MTS test as described previously [15, 16]. Cells/scaffolds contructs $(n=6)$ were washed in $0.15 \mathrm{M}$ PBS and placed in a mixture containing complete culture medium (without FBS) and MTS in a 5:1 ratio and incubated for $3 \mathrm{~h}$ at $37^{\circ} \mathrm{C}$ in a humidified atmosphere containing 5\% $\mathrm{CO}_{2}$. After $3 \mathrm{~h}$ O.D. was read at $490 \mathrm{~nm}$. Results are presented as O.D./scaffold.

\subsubsection{Cell proliferation assay}

Cell proliferation of SaOS-2 cells on the premineralized and non mineralized starch based scaffolds was assayed after $12 \mathrm{~h}, 7$ and 14 days by a total protein assay, the Sedmak method, as described previously [16]. Briefly, at each time point cells/scaffolds constructs were washed in $0.15 \mathrm{M}$ PBS, placed in $750 \mu \mathrm{l}$ of lysis buffer (20 mM Tris, $1 \mathrm{mM}$ EDTA, $150 \mathrm{mM} \mathrm{NaCl}$ and $1 \%$ Triton X-100) supplemented with $100 \mu \mathrm{M}$ phenylmethylsulfonyl fluoride (PMSF, Sigma, USA) and a cocktail of proteinase inhibitors (Chymostatin, Leupeptin, Antipain, Pepstatin) in a final concentration of $1 \mathrm{mg} / \mathrm{ml}$, and finally sonicated at $40 \mathrm{Kv}$ for $3 \times 15 \mathrm{~s}$. Protein extracts were then submitted to a centrifugation, after which the pellets were rejected. Scaffolds without cells, but in the same culture conditions were used as blanks. Finally $20 \mu \mathrm{l}$ of the protein extracts were added to $2 \mathrm{ml}$ of Sedmak reagent and the O.D. read at $620 \mathrm{~nm}$. The results were then plotted against a standard curve made with bovine serum albumin (BSA) ranging from 0 to $25 \mu \mathrm{g}$. Total protein was finally calculated by extrapolation for the $750 \mu \mathrm{l}$ of protein extract solution. Results are shown as total protein/scaffold.

\subsubsection{Alkaline phosphatase activity}

Alkaline phosphatase (ALP) activity from the scaffolds/cells constructs was quantified by the specific conversion of p-nitrophenyl phosphate (pNPP) into para-nitrophenol (pNP). Supernatants were collected after $12 \mathrm{~h}, 7$ and 14 days $(n=6)$, frozen at $-20^{\circ} \mathrm{C}$ and then thawed prior to analysis. The enzyme reaction was set up by mixing $50 \mu \mathrm{l}$ of the sample with $150 \mu \mathrm{l}$ of substrate buffer containing $1 \mathrm{M}$ Diethanolamine $\mathrm{HCL}(\mathrm{pH}$ $9,8)$ and $2 \mathrm{mg} / \mathrm{ml}$ of pNPP. The solution was incubated at $37^{\circ} \mathrm{C}$ for $30 \mathrm{~min}$ and the reaction was then stopped by a solution containing $2 \mathrm{M} \mathrm{NaOH}$ and $0.2 \mathrm{mM}$ EDTA in distilled water. The optical density was determined at $405 \mathrm{~nm}$ with a reference filter at $620 \mathrm{~nm}$. A standard curve was made using $\mathrm{pNP}$ values ranging from 0 to 0.6 $\mu \mathrm{mol} / \mathrm{ml}$. Results are shown in $\mathrm{U} / \mu \mathrm{g}$ protein $/ \mathrm{scaffold}$.

\subsubsection{Western immunoblot analysis}

For western immunoblot analysis, protein was extracted after 7 and 14 days and quantified as described in 2.4.4. Aliquots containing equal amounts of protein $(20 \mu \mathrm{g})$ were submitted to an electrophoresis and then electrotransferred to a Hybond P membrane (Amersham,
USA). After blocking the membranes, blots were then further incubated for $1 \mathrm{~h}$, at room temperature, with primary antibodies against osteopontin (University of Iowa, USA) and collagen I (Southern Biotechnology Associates, USA) both in a 1:200 dilution. After washing, blots were further incubated for $1 \mathrm{~h}$ with anti-mouse IgG antibody (Amersham, USA), for anti-osteopontin blots, and anti-goat IgG antibody (Pierce, USA) for collagen blots, both coupled to horse radish peroxidase. The immune complex was then detected by incubation with ECL system (Amersham) and visualized by chemiluminescence.

\subsection{Statistics}

Results are expressed as mean values \pm standard deviation for each group of samples. Statistical evaluation was performed using two-tailed paired $t$ student tests to assess statistical differences between the different groups. Statistical significance was defined as $p<0.05$ for a $95 \%$ confidence interval.

\section{Results and discussion}

\subsection{Scaffolds characterization}

As it was recently reported by Oliveira et al. [19], the biomimetic coating methodology described in the present work allows for the formation of a partially amorphous Ca-P layer, with Ca-P ratios similar to those found on human bone natural occurring $\mathrm{HA}$, on the surface of starch based biodegradable scaffolds.

SEM observation demonstrated that the methodology was effective to coat both the surface and the bulk of the scaffolds. This data can be observed in Fig. 1, in which it can be seen that both the bars of the scaffolds (Fig. 1(d)) and the inner walls of the pores (Fig. 1(e) and (f)) were coated. Furthermore, this same set of results showed that the referred to treatment did not affect the pore size and the porosity. This property is particularly important due to the importance of porosity for cell growth and viability, as well as for vascular vessels ingrowth.

Further important data that resulted from the present experiment indicated that the mechanical properties of the material were not deleteriously affected. As it can be seen in Fig. 2, mechanical properties of the modified $3 \mathrm{D}$ porous structures were improved when compared to those of the control samples (Figs. 2 and 3$)(p<0.05)$. These results are probably connected with the deposition of the Ca-P layer on the scaffolds. As it is known this is a ceramic and hence can increase the mechanical properties of the materials that are being used. However, this fact by itself would not be responsible for such a significant difference between the coated and non-coated. In this sense it is also believed that the leaching of a small amount of plasticizer during the SBF immersion time may also have a minor role on the increase of the mechanical properties. At the same time mechanical properties were also similar to those found for trabecular bone, showing that the developed coated scaffolds may have enough mechanical stability to be used for bone tissue engineering purposes. 

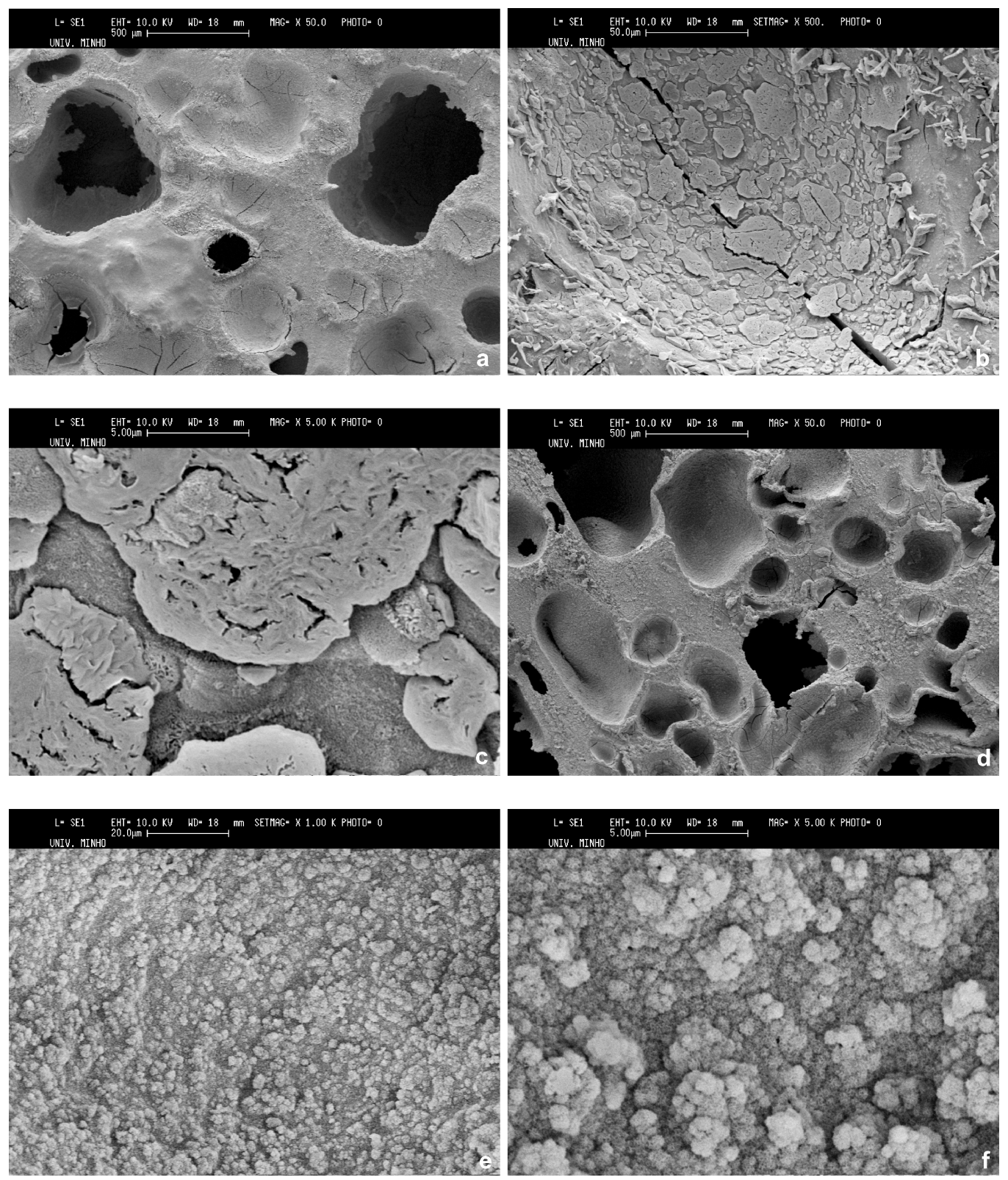

Figure 1 Scanning electron microscopy observation of starch based scaffolds after 14 days immersion in a simulated body fluid (SBF) solution: (a), (b), (c) non treated samples; (d), (e), (f), treated with a sodium silicate gel solution as a nucleative agent. Notice that the treatment did not close the pores and did not affect the interconnectivity of the porous scaffolds. Moreover, the walls of the pores were also effectively coated with a Ca-P layer $(\mathrm{e}, \mathrm{f})$, being demonstrated that by using this technique it is possible to coat both the surface and the bulk of the scaffold.

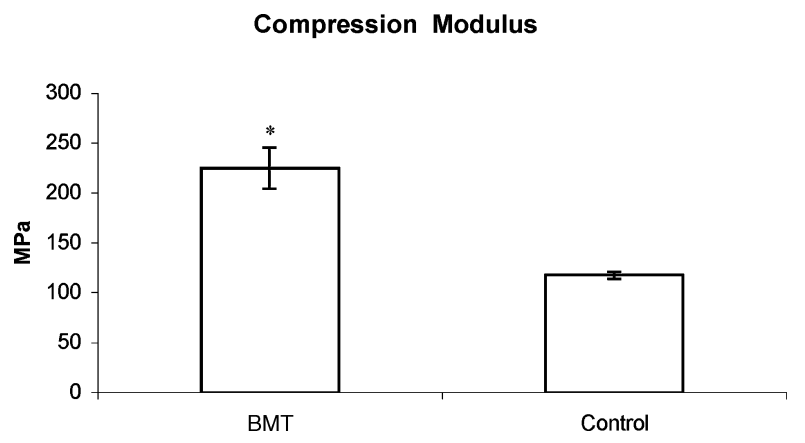

Figure 2 Compressive modulus of non-treated (control) and sodium silicate treated (BMT) after 14 days of immersion in a SBF solution $(n=6$, $\pm \mathrm{sd} ; * p<0.05)$.

\subsection{Cytotoxicity assays}

Regarding short-term MEM extraction tests, the results demonstrated that leachables from the Ca-P coated

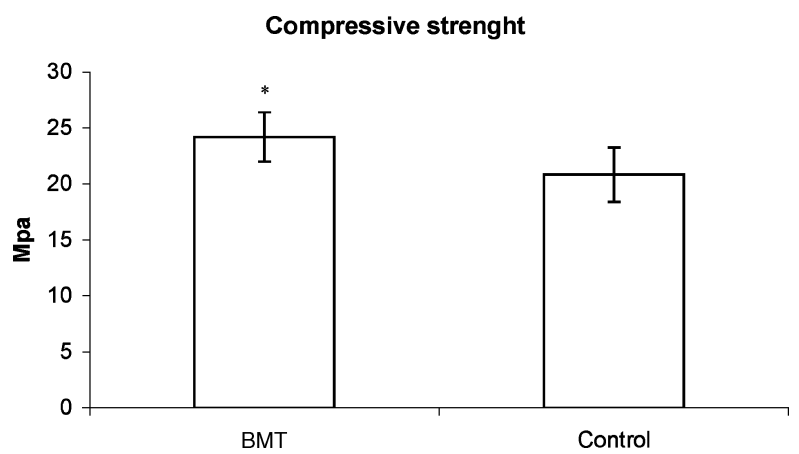

Figure 3 Compressive strength of non-treated (control) and sodium silicate treated (BMT) after 14 days of immersion in a SBF solution $(n=6$, $\pm \mathrm{sd} ; * p<0.05)$.

samples did not cause growth inhibition after $72 \mathrm{~h}$, having similar results to those obtained for the noncoated samples. As it is shown in Fig. 4 cells incubated with the extracts from the Ca-P coated samples 


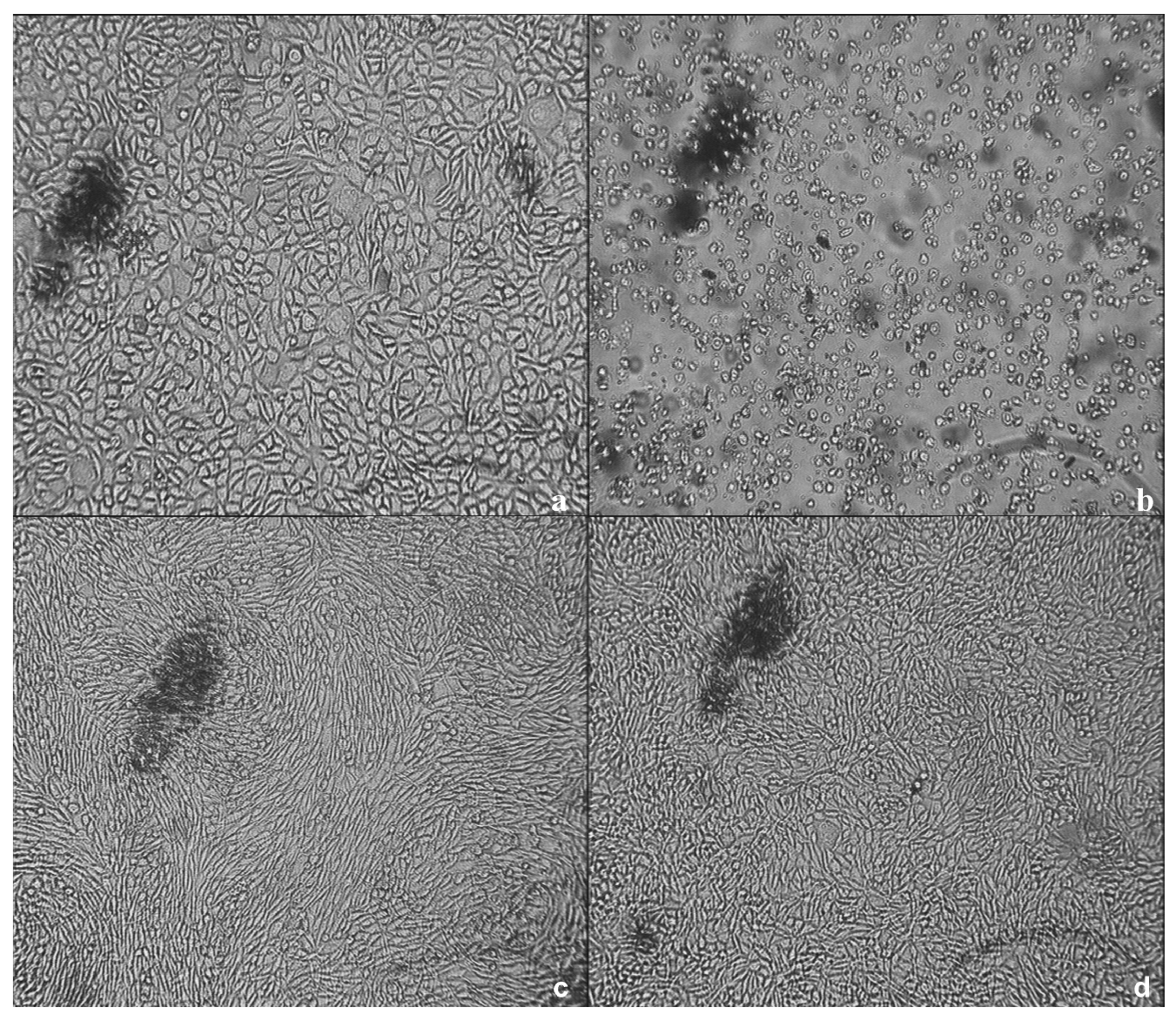

Figure 4 L929 cells incubated with extracts obtained from (a) negative control, (b) positive control, (c) untreated SEVA-C scaffolds and (d) biomimetic treated SEVA-C scaffolds, over a $72 \mathrm{~h}$ period. $(100 \times$ magnification $)$

presented minor alterations in their morphology when compared with both the negative control and the noncoated SEVA-C samples (Fig. 4(a), (c), and (d)). These alterations are probably related with the slightly higher proliferation indexes of both the negative control and non-coated SEVA-C samples, which lead the latter to higher degrees of confluence. After the combination of the several scores, as referred in the materials and methods section, the tested material had a cytotoxic index of 0.2 (Table III). These results are not typical at all of biodegradable polymers that are currently being used within the bone tissue engineering field.

Regarding MTS test, L929 cells produced large amounts of a brown formazan product, which indicates strong MTS reduction and high metabolic rates by the cells (Fig. 5). The results obtained were similar to those of negative control and non-coated samples. This fact clearly indicates that the developed Ca-P coated 3D porous structures not only were non toxic but they also did not cause any deleterious alteration on the raw material.

As a conclusion, and after combining the results from both the MEM extraction and MTS tests, it can clearly

TABLE III Short MEM extraction test cytotoxicity results

\begin{tabular}{ll}
\hline Sample & Cytotoxixity index \\
\hline SEVA-C Ca-P coated & 0.2 \\
SEVA-C Non-coated & 0.1 \\
\hline
\end{tabular}

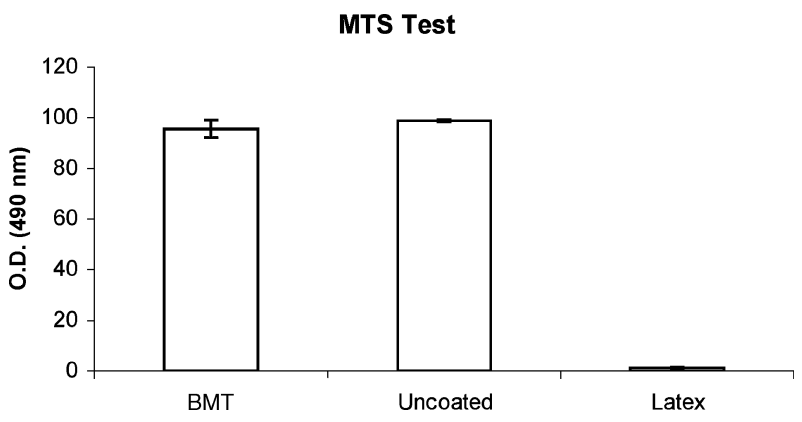

Figure 5 MTS reduction by L929 cells after incubation with the test and positive control extracts over a period of $72 \mathrm{~h}$. Results are based on optical density measurements and were normalized for the negative control.

be stated that the leachables from SEVA-C scaffolds coated with a Ca-P layer are not harmful to the cells. Therefore, the materials can be considered as being non cytotoxic.

\subsection{Direct contact assays}

The initial in vitro interaction between cells and a certain biomaterial is commonly mediated by a previously adsorbed layer of protein resultant from cell culture medium [21, 22]. However, within the present study a new factor was introduced, a Ca-P layer. In this context cells will interact with a Ca-P layer and the proteins adsorbed on it. This fact may affect not only the pattern of adhesion of osteoblast like cells to the material, 

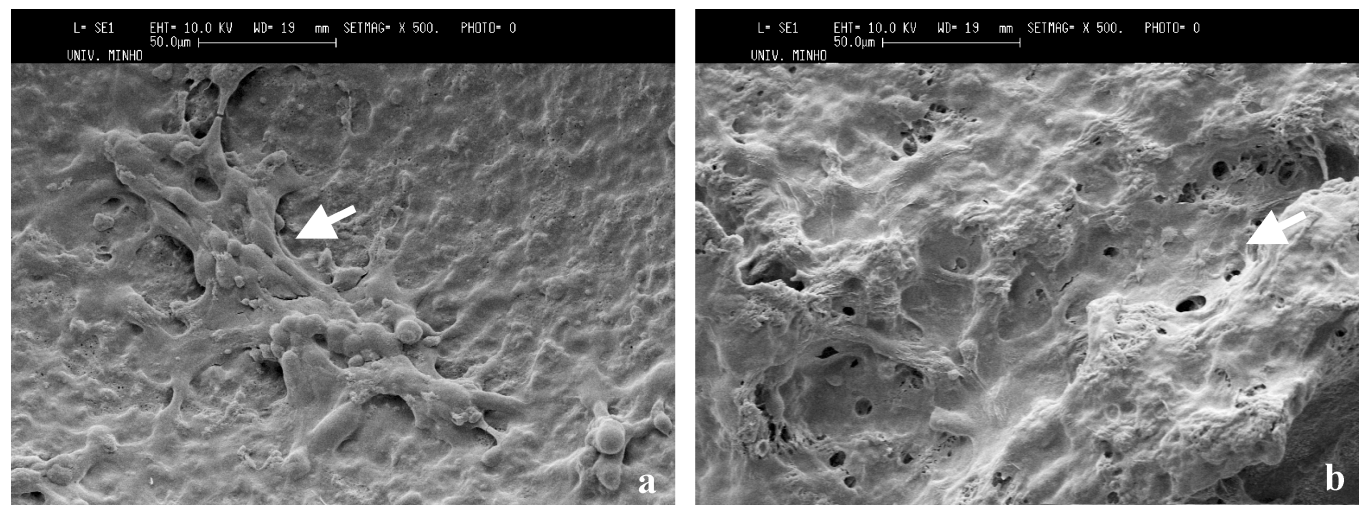

Figure 6 Scanning electron microscopy (SEM) of SaOS-2 cell adhesion and proliferation on non treated (a) and biomimetic treated (b) SEVA-C based scaffolds after 14 days in culture.

but also reorganisations in their cytoskeleton as well as different gene expression profiles [23-25].

Regarding the present experiment, SEM observation showed that cells were already well adhered to the material after just one day in culture (data not shown), being present mainly on the cell walls of the porous scaffold. However, some differences concerning cell morphology could already be detected. Human osteoblast like cells had a more spread and flattened morphology than those seeded on the non-coated samples, which indicates a stronger cellular adhesion (data not shown). After day 1 , cells start to grow and colonize both the Ca-P coated and control scaffolds. By the end of the first (data not shown) and second week of the experiment the degree of colonization of the scaffolds was higher and some of the pores were already been taken up by some cells (Fig. 6). At the same time multi-layered skeletal structures, typical of extracellular matrix (ECM) deposition, were found in cells colonizing the inner pores of the Ca-P coated scaffolds. The same differences in the morphology registered just after one day in culture were also observed after 1 (data not shown) and 2 weeks (Fig. 6). As it can be observed in Fig. 6 osteoblast-like cells presented different morphologies when in contact with the surface of the two different scaffolds. Although they were able to adhere and grow on both substrates, SaOS2 cells seeded onto the Ca-P coated scaffold seemed to have undergone a different cytoskeletal rearrangement presenting a more flattened and spread morphology (arrows), when compared to the cells seeded on the control samples (arrows). These results prove that the phenomena observed just after 1 day in culture was not accidental. This fact is coherent when compared with the data found in the literature [10]. Previous studies had already shown that when in contact with Ca-P coatings osteogenic cells not only seem to have better adhesion patterns, but would also undergo cytoskeleton reorganisation, presenting different morphologies when compared to non-coated samples $[6,9,12]$.

Total protein results (Fig. 7) showed that cells were able to proliferate within both coated and uncoated samples. However, the values obtained for Ca-P coated samples were always smaller when compared to the control, being the differences significative different after $12 \mathrm{~h}$ $(p<0.05)$ and 14 days $(p<0.05)$. These differences are mainly related with two factors. Firstly, samples,
Cell Proliferation

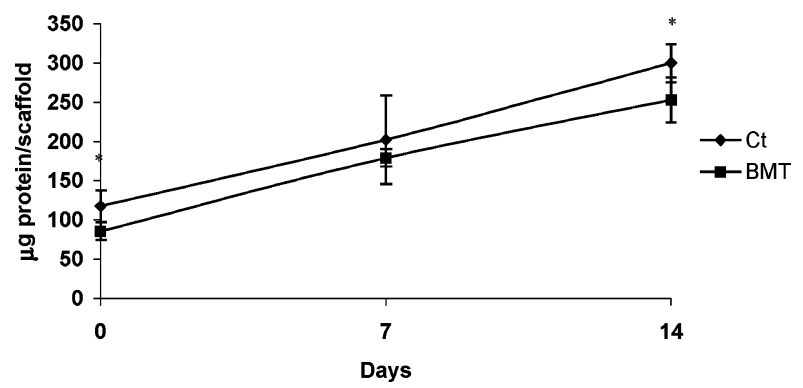

Figure 7 Cell proliferation was weekly assessed by means of a total protein assay. Cell density used was $3 \times 10^{5}$ cells/scaffold $(\mathrm{Ct}-$ nontreated samples; BMT-biomimetic treated samples). Cells were kept in culture for 14 days in complete culture medium supplemented with $5 \mathrm{mM}$ $\beta$-glycerophosphate, $50 \mu \mathrm{M}$ ascorbic acid $\left(n=6, \pm \mathrm{sd}\right.$; $\left.{ }^{*} p<0.05\right)$.

which suffer the sodium silicate and biomimetic treatments, were slightly more hydrophobic than the control samples. Because of this, their capability of absorbing the cell suspension was diminished and so, the amount of cells that was able to adhere to the modified scaffolds was smaller. The second reason by which the growth was smaller on the Ca-P coated samples during the second week of growth is probably related with the deposition of extracellular matrix or its mineralization, as it will be discussed later.

Cell viability assays (MTS test) showed that cells remained viable for the two weeks of the experiment, with increasing metabolic rates (Fig. 8), which are associated with an increasing cell number. Differences on the O.D. values were found to be significant after $12 \mathrm{~h}(p<0.05)$ (higher O.D. for control samples) and 7 days $(p<0.05)$ (higher O.D. for treated samples), and non significative after 14 days $(p>0.05)$. Regarding the differences obtained for just after $12 \mathrm{~h}$ they are related with the higher hydrophobicity of the treated samples as described earlier. The differences registered for the first week are mainly related with the different growth rates of the cells. When analysing the data from total protein, it is clear that cells seeded on the modified samples had a faster growth rate when compared to the control. Because of this, it is logical that the overall metabolic rate was increased and hence the amount of MTS incorporated and reduced by the cells was higher 
MTS Test

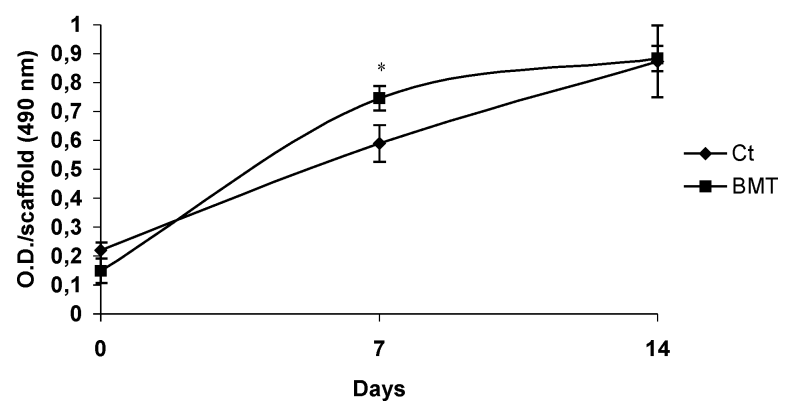

Figure 8 Cell viability was weekly assessed by means of MTS test. Cell density used was $3 \times 10^{5}$ cells/scaffold $(\mathrm{Ct}-$ non-treated samples; BMT-biomimetic treated samples). Cells were kept in culture for 14 days in complete culture medium supplemented with $5 \mathrm{mM} \beta$ glycerophosphate, $50 \mu \mathrm{M}$ ascorbic acid $\left(n=6, \pm \mathrm{sd} ;{ }^{*} p<0.05\right)$.

in those that were growing in the modified scaffolds. Finally, and after two weeks of growth the O.D. values were similar. These values are once again related with the growth rate of the cells as well as with other phenomena such as matrix deposition and consequent mineralization.

Western immunoblot analysis showed that osteopontin and collagen I were being expressed by human osteoblast like cells seeded on both $\mathrm{Ca}-\mathrm{P}$ coated and on uncoated scaffolds.

Collagen I is the most abundant protein in bone ECM. Together with other forms of collagen and bone specific glycoproteins forms hydroxyapatite embedded heterofibrils, that reveal unmatched mechanical properties concerning load bearing, tensile strength and torsional resistance [26]. Furthermore, besides being involved in the formation of mineralized bone matrix it also involved in such important processes such as cell adhesion, proliferation and differentiation of osteoprogenitor cells $[26,27]$. In this sense, it can be said that the presence of collagen I is essential for the synthesis of a solid and functional bone extracellular matrix.

Osteopontin, which was first described by Senger et al. [28] as a secreted phosphoprotein, is another bone extracellular constituent protein. As recently reviewed by Sodek et al. [29], this protein is involved in several processes that occur in remodelling bone such as cell adhesion, bone resorption, the bridging between cells and HA, and between bone matrix and mineral, as well as bone matrix mineralization. In vitro, its expression is also detected and it is commonly associated with the formation of a collagen-free cement layer upon which bone is subsequently deposed. When observing Fig. 9 it is clearly seen that osteopontin was expressed after 1 and 2 weeks, while collagen I expression was only detected after two weeks. Together with the data observed by SEM (Fig. 6), these results indicate that active bone extracellular matrix deposition was occurring.

ALP is a membrane-bound enzyme that hydrolyses phosphate esters, being also secreted into the extracellular millieu. It is commonly referred as an initial marker of the osteogenic phenotype and it is involved in the initial processes of bone extracellular matrix mineralization [30].

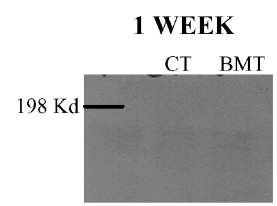

(a)

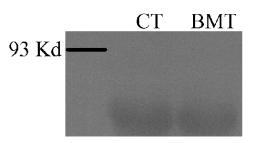

(c)

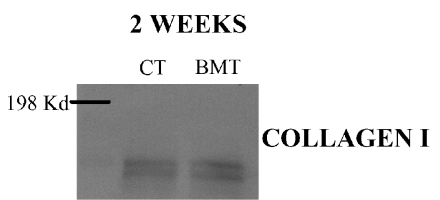

(b)

(d)

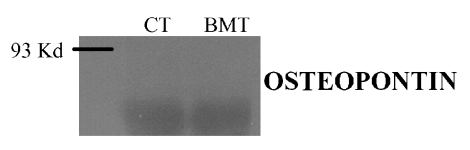

Figure 9 Western blot analysis of collagen I (a, b) and osteopontin (c, d) expression of SaOS-2 cells seeded on starch based scaffolds $(\mathrm{Ct}-$ nontreated samples, BMT-biomimetic treated samples) after 1 (a, c) and 2 weeks $(b, d)$ respectively. Expression of the referred proteins indicates the deposition of bone extracelullar matrix (ECM).

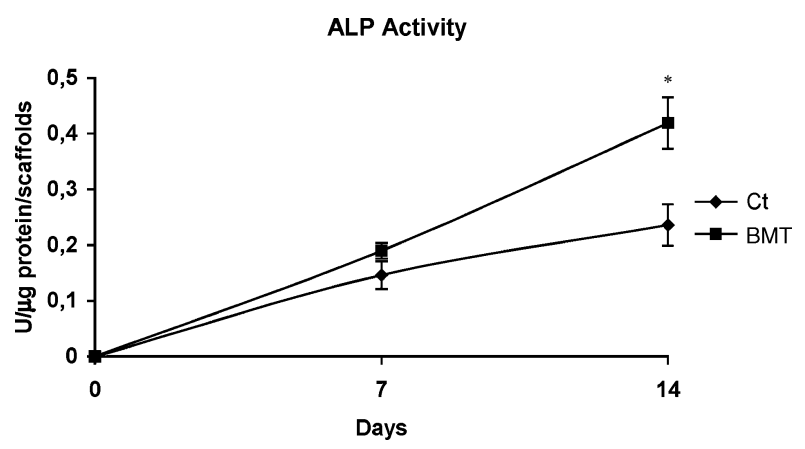

Figure 10 ALP actvity assay: supernatants were weekly collected and frozen. After 2 weeks supernatants were thawed. The results are shown in $\mathrm{U} / \mu \mathrm{g}$ protein/scaffold in function of days. $\left(n=6, \pm \mathrm{sd}\right.$; ${ }^{*} p<0.05$; $\mathrm{Ct}$ - control and BMT-biomimetic treated).

Regarding the present experiment, ALP activity experiments showed that after two weeks the activity of this enzyme was higher, and significantly different $(p<0.05)$, in the supernatants collected from the $\mathrm{Ca}-\mathrm{P}$ cells/scaffolds constructs. This fact indicates that a faster mineralization of the extracellular matrix deposited on the Ca-P coated scaffolds was happening. Furthermore, it also shows why the growth was smaller during the second week. The onset of matrix mineralization (calcium and phosphate deposition) is regularly associated with a decrease on cell proliferation $[31,32]$.

The different ALP activity profiles are probably related with the cristallinity degree or the roughness of the Ca-P layer deposed. Studies by ter Bruge et al. [9] have shown that the osteogenic phenotype of osteoblast like cells was dramatically increased when these cells were put in contact with $\mathrm{Ca}-\mathrm{P}$ coated surfaces. Another possible reason is the roughness of the $\mathrm{Ca}-\mathrm{P}$ layer when compared to the uncoated material. When cells are in contact with rougher surfaces their cytoskeleton reorganizes trough actin filaments rearrangement, which will lead to a different gene expression profile [23-25, 33]. Finally, the dissolution products from the coatings can also play a role in the upregulation of the osteogenic phenotype, as described previously [9].

Nevertheless further studies should be conducted in order to fully understand the mechanisms triggered by the $\mathrm{Ca}-\mathrm{P}$ coatings that were described in this work. 


\section{Conclusions}

The sodium silicate gel biomimetic coating methodology proved to be very effective in the production of a $\mathrm{Ca}-\mathrm{P}$ layer on the surface of starch based biodegradable scaffolds. Moreover this methodology did not cause any alterations of the materials non-toxic behaviour, as demonstrated by both MEM and MTS tests. Direct contact assays showed that cells were able to proliferate within the Ca-P layer of the modified scaffolds, demonstrating its adequacy for cell growth. Finally protein expression studies clearly indicated that a faster mineralization of the extracellular matrix was happening in the Ca-P cells/scaffolds constructs. This fact may also indicate that these biomimetic coatings may be osteoinductive and therefore might be able to increase the differentiation rate of human osteoblast like cells into a more differentiated osteogenic phenotype, and consequently could be useful for bone tissue engineering applications.

\section{Acknowledgments}

A.J. Salgado was supported by scholarship SFRH/ $3139 / 2000$ from the Portuguese research council "Fundação para a Ciência e Tecnologia" (FCT).

The authors would like to acknowledge Luciano Boesel for the help given with the mechanical testing and characterization of the developed materials.

The monoclonal antibody, MPIIIB $10_{1}$, developed by Michael Solursh and Ahnders Franzen was obtained from the Developmental Studies Hybridoma Bank developed under the auspices of the NICHD and maintained by The University of Iowa, Department of Biological Sciences, Iowa City, IA 52242.

\section{References}

1. H. PEtite, V. Viateau, W. BENSAid, A. MEUNIER, C. DE POLLAK, M. BOURGUIGNON, K. OUDINA, L. SEDEL and G. GUILLEMIN, Nat. Biotech. 18 (2000) 959.

2. R. SPITZER, C. PERKA, K. LINDENHAYN and H. ZIPPEL, J. Biomed. Mat. Res. 59 (2002) 690.

3. G. C. SIMON, C. A. KHATRI, S. A. WIGHT and F. W. WANG, J. Orthop. Res. 20 (2002) 473.

4. R. LANGER and J.P. VACANTI, Science 260 (1993) 920.

5. S. YANG, K. LEONG, Z. DU and C. CHUA, Tissue Eng. 7(6) (2001) 679.

6. P. A. RAMires, A. Romito, F. Cosentino and E. MILELLA, Biomaterials 22 (2001) 1467.

7. Y. ZHANG and Z. ZHANG, J. Biomed. Mat. Res. 61 (2002) 1.

8. H. YUAN, Z. YANG, J. D. DE BRUIJN, K. DE GROOT and X. ZHANG, Biomaterials 22 (2001) 2617.
9. P.J. TER BRUGGE, J. C. G. WOLK and J. A. JANSEN, J. Biomed. Mat. Res. 60 (2002) 70.

10. J. E. G HULSHOFF, K. VAN DIJK, J. E. DE RUIJTER, F. J. R. RIETVELD, L. A. GINSEL and J. A. JANSEN, ibid. 40 (1998) 464.

11. Y.-L. CHANG, C. M. STANDFORD, J. S. WEFEL and J. C KELLER, Int. J. Oral Maxillofac. Implants 14 (1999) 239.

12. J. L. ONG, D. R. VILLARREAL, R. CAVIN and K. MA, J. Mat. Sci.: Mat. Med. 12 (2001) 491.

13. M. E. GOMES, J. S. GOdinho, D. TCHALAmov, A. M. CUNHA and R. L. REIS, Mat. Sci. \& Eng. C 20 (2002) 19.

14. M. E. GOMES, A. S. RIBEIRO, P. B. MALAFAYA, R. L. REIS and A. M. CUNHA, Biomaterials 22 (2001) 883.

15. A. J. SAlgAdo, M. E. GOMES, A. CHOU, O. P. COUTINHO, R. L. REIS and D. W HUTMACHER, Mat. Sci. Eng. C 20 (2002) 27.

16. A. J. SAlgADO, O. P. COUTINHO and R. L. REIS, Tissue Eng. 10 (2004) 665.

17. R. L. REIS, A. M. CUNHA, M. H. FERNANDES and R. N. CORREIA, J. Mat. Sci.: Mat. Med. 8 (1997) 897.

18. A. L. Oliveira, C. ElvirA, B. VÁSQUEZ, J. SAN ROMAN and R. L. REIS, ibid. 10 (1999) 827.

19. A. L. OliveirA, P. B. MALAFAYA and R. L. Reis, Biomaterials 24 (2003) 2575.

20. Iso/document 10993. Biological compatibility of medical devicesPart 5. Test for cytotoxicity: in vitro methods, December 1992.

21. J. G. Steele, B. A. DAlton, C. H. Thomas, K. E. HEALY, T. R. GENGENBACH and C. D. MCFARLAND, in "Bone Engineering" (m squared, Toronto, 1999) p. 225.

22. T. A. HORBETT, K. W. COOPER, K. R. LEW and B. D. RATNER, J. Biomater. Sci-Polym. Ed. 9 (1998) 1071.

23. D. P. PIOLETTI, H. TAKEI, T. LIN, P. VAN LANDUYT, Q. J. MA, S. Y KWON and K. -L. P. SUNG, Biomaterials 21 (2000) 1103.

24. J. P. BIDWELl, M. ALVAREZ, H. FEISTER, J. ONYIA and J. HOCK, J. Bone Min. Res. 13 (1998) 155.

25. C. S. CHEN, M. MRKSICH, S. HUANG, G. M. WHITES IDES and D. E. INGBER, Science 276 (1997) 1425.

26. K. VON DER MARK, in "Dynamics of Bone and Cartilage Metabolism” (Academic Press, 1999) p. 3.

27. G. XIAO, D. WANG, M. D. BENSON, G. KARSENTY and R. T FRANCESCHI, J. Biol. Chem. 273(49) (2002) 32988.

28. D. R. SENGER, D. F. WIRTH and R. O. HYNES, Cell 1 (1979) 885.

29. J. SODEK, B. GANSS and M. D. MCKEE, Crit. Rev. Oral. Bio. Med. 11(3) (2000) 279.

30. J.E. AUBIN, K. TURKSEN and J.N.M. HEERSCHE, in "Cellular and Molecular Biology of Bone" (Academic Press, New York, 1994) p. 1.

31. L. D. SHEA, D. WANG, R. T. FRANCESHI and D. J. MOONEY, Tissue Eng 6(6) (2000) 605.

32. V. I. SIKAVITSAS, G. N. BANCROFT and A. G. MIKOS, J. Biomed. Mat. Res. 62 (2002) 136.

33. U. MAYR-WOHLFART, J. FRIEDLER, K.-P. GUNTHER, W. PUHL and S. KESSLER, ibid. 57 (2001) 132.

Received 2 June 2003

and accepted 23 June 2004 